\title{
MASSIVE GENETIC INTROGRESSION AMONG ACONITUM (RANUNCULACEAE) SPECIES IN A MOUNTAIN HYBRID ZONE
}

\author{
Agnieszka Sutkowska ${ }^{1}$, Piotr Boron ${ }^{1}$, Tomasz Warzecha ${ }^{1}$, and Józef Mitka ${ }^{2}$ \\ ${ }^{1}$ University of Agriculture in Krakow \\ ${ }^{2}$ Jagiellonian University
}

May 6, 2021

\begin{abstract}
HHybridization in Aconitum is a widespread phenomenon. However, the introgression between the diploid and tetraploid species is rare. We studied species of different ploidy in a mountain hybrid zone in the Tatra Mts (West Carpathians). In this paper, we aimed to identify the extent of introgressive hybridization using PCR-ISSR fingerprinting and chloroplast DNA (cpDNA) sequencing. The diploid and tetraploid species had different cpDNA haplotypes, and the triploid hybrid was stabilized on the tetraploid level. ISSR markers showed the locally pervasive introgression, but genetic introgressants were not morphologically changed. Principal Coordinates Analysis, NeighborNet clustering, and Bayesian inference showed close genetic links between individuals in the same population but populations were significantly genetically differentiated $(\mathrm{FST}=0.129, \mathrm{p}<0.001)$. A genetic model of introgression via the triploid bridge was proposed. Genetic introgression does not seemingly pose a threat to species taxonomic identity. The genetic differences between the same species in different populations advocate for a web-of-life than a biological species concept. Genetic introgressants in the isolated mountain populations make each of them genetically unique.
\end{abstract}

\section{Hosted file}

AconitumOK_JM.pdf available at https://authorea.com/users/412262/articles/521009-massivegenetic-introgression-among-aconitum-ranunculaceae-species-in-a-mountain-hybrid-zone

\section{Hosted file}

Figures caption.pdf available at https://authorea.com/users/412262/articles/521009-massivegenetic-introgression-among-aconitum-ranunculaceae-species-in-a-mountain-hybrid-zone 